\title{
Decolonisation and Food: The Burden of Colonial Gastronomy - Stories from West Bengal
}

\section{Sayan Dey}

ORCID iD: https://orcid.org/0000-0002-7569-5519

\author{
Rozena Maart \\ ORCID iD: https://orcid.org/0000-0002-3829-1523
}

\begin{abstract}
This article makes an effort to unpack the ways in which the traditional food customs of precolonial Bengal were colonised by the Europeans, especially the British, followed by the Portuguese. In the course of its unpacking, the article reflects rather elaborately, as the details reveal, on how the colonisation of food customs and culinary practices of precolonial Bengal opened gateways for the Europeans to fragment the traditional society of precolonial Bengal socially, culturally, racially and communally. With scant references to the colonisation of food in Cape Town, South Africa, where the Dutch brought Bengali families in the middle of the 1600s as enslaved peoples to assist them in setting up a halfway station for their continued colonisation of India, this article also explores the various possibilities of decolonising the colonial and capitalistic invasions of European and North American food customs and culinary practices in contemporary West Bengal, in particular.
\end{abstract}

Keywords: Traditional food customs, precolonial Bengal, colonisation, culinary practices, decolonising food practices

\section{Introduction}

This article unpacks the ways in which the traditional food customs of preco- 
lonial Bengal were colonised by the Europeans, especially the British, followed by the Portuguese. In the course of its argument, the article reflects rather elaborately, as the details reveal, on how the colonisation of food customs and culinary practices of precolonial Bengal opened gateways for the Europeans to fragment the traditional society of precolonial Bengal socially, culturally, racially and communally. With scant references to the colonisation of food in Cape Town, South Africa, where the Dutch brought Bengali families in the middle of the 1600s as enslaved peoples to assist them in setting up a halfway station for their continued colonisation of India, this article also explores the various possibilities of decolonising the colonial and capitalistic invasions of European and North American food customs and culinary practices in contemporary West Bengal, in particular.

\section{Subject Location: A Political Point of Departure}

In introducing this article, we assert our political point of departure as a means to offer our subject location, both in terms of our personal interest and political commitment to the process of decolonisation as a Bengali man born in India, and a Black South African woman, whose heritage stems from the old slave quarter of the Cape: whose maternal grandmother's heritage is directly linked to the enslavement of the Bengali from Bengal, India and the Bengali Javanese from Indonesia by the Dutch and trafficked to the Cape, and whose maternal grandfather's heritage stems from the Xhosa people of the Eastern Cape. We situate these subject identities as part of a larger practice focused on the dayto-day activities of the colonised, of which we are both a part. We wish to assert from the outset that colonisation, which first and foremost stages itself upon the mind and the body of the colonised (Biko 1978: 25) can only fully be addressed upon the full realisation of its multi-layered operation. And, whilst this is a painstaking process for the colonised, for the most part, the consciousness derived during the stages of its unpacking provide a possibility for understanding the social and material conditions that were constructed in order for colonialism to flourish; the knowledge of these social and material conditions, which we take up later in this article, offer us a broad spectrum from which to locate the many ways in which colonisation was staged upon the mind, body and soul, and as this article demonstrates more precisely, the palate of the colonised (Palates of Pleasure, Maart \& Dey forthcoming). 


\section{Methodology}

In this article, we examine culture as a key component of the social conditions of usurpation and colonialism, linking culture and identity to food as a practice of being-in-the-world that is central to the daily life of the colonised, which the coloniser seizes and appropriates (Palates of Pleasure, Maart \& Dey forthcoming). Existentialism allows us the possibility of reflecting upon how we exist in the world, as well as the possibility of understanding our respective contexts through the many relations of our engagement within the world. We will, as such, address some of these existential elements that motivated us to engage with the phenomenon of decolonisation and decoloniality as scholars relaying our experiences, whilst also relying on the social research method of auto-ethnography, which offers us the benefit of a select number of narratives, which simultaneously situate our locations as well as sets up the context from which we draw.

One author was born within a Bengali family in the city of Kolkata and his mother tongue is Bengali. Since his childhood days, he observed that both his parents and grandparents made a concerted effort to introduce him to various forms of writing in the Bengali language. Given the overwhelming presence of the English language across the British colonies, India was, and remains, no exception. The other author was born in Cape Town within a family where her grandparents were the head of the household; her maternal grandmother spoke openly of her Bengali and Hindu heritage. This was not only evident by her dress and physical appearance and the fact that she was racialised and the subject of racial slurs in the street that were directed at her Indian heritage but also because an oral tradition of handing over ancestral information from one generation to the next was an active practice in the old slave quarters of the Cape as it is in many communities on the African continent and in the African diaspora. Her maternal grandfather was a Xhosa man, who married her grandmother after her first husband passed on; that marriage, due to the laws of apartheid, only took place in 1954, when her mother was 16 years old. The combination of their culinary skills was passed on to the said author which she relishes to this day. The knowledge upon meeting her paternal grandmother the week of her 19th birthday, brought the history of her culinary interest to full circle. It was revealed then that her paternal grandmother had met her paternal grandfather in a hotel where she worked as the cook. The love and joy in preparing food and delighting in the 
varied cuisine her culture has to offer through its indigenous plants, its sea (knowledge gained from her maternal grandfather who was also a fisherman) and the efforts of the Dutch and the British in acquiring spices from India in their colonising conquest, all of which South Africa has an abundance of, are all drawn into the colourful and flavourful array of the plates that were created in her hotel and in her neighbourhood, which the author reproduces in her home. As such, as co-authors we also cite our collaborative work, Palates of Pleasure, which provides a historical journey and critique of food, culture, community, colonisation and desire in our respective locations of Bengal and Cape Town, where we also trace the acts of colonisation by our common colonisers, the British, Dutch, Portuguese and the French.

For the purpose of this article, the Bengali author will centre his experiences, and draw from them when asserting the history of Bengali cuisine that came to define his palate; the South African author does not take the same approach in this collaboration but one which offers an integration of their joint analysis and critique. All forms of expression that refer to 'I' reflect on the Bengali author who centres his family's culinary history throughout the article. The autoethnographic narratives shared and foregrounded are those of the Bengali author. It is our belief, given the parameters of a journal article, that this collaboration offers readers an opportunity to understand the history of colonisation of Bengali gastronomy, which for the purpose of this article, remains our primary focus. This article explores various social, cultural, racialised and communal factors that led to the disruption of Indigenous food customs and culinary practices in Bengal during the colonial era and its continuity in the contemporary modern-day Bengal.

\section{Food, House, Language, Home and Away}

For the Bengali author, the persistence of his Bengali parents and grandparents enabled the Bengali in him to remain rooted in his mother tongue, and on the other hand, allowed him to evolve epistemologically and ontologically in a contextual manner, understanding his location, language, culture, identity, food customs and practices, as something that they owned and passed on to him. He understood the latter more profoundly over the years as intellectual property and ancestral property.

When he was admitted to an English medium school for the first time, the British colonial pedagogical practices made him feel very disconnected 
from his Bengali identity and rather uncomfortable; he realised, much later, that such pedagogical practices meant to. At that time, whilst he was not acquainted with terms such as colonialism, postcolonialism, decolonialism, coloniality, postcoloniality and decoloniality, he sensed that something was terribly awry. The comfort and ease that he was afforded while reading and learning in Bengali at his home did not happen at his school when he was taught the English language, mannerisms and expressions.

Let me now take a more personal approach, as I utilise the term 'I' and direct the personal impact of my family history. During the latter part of my schooling, I realised that English is not only a language, but an authoritative phenomenon imposed by the British colonisers, that pushed me to act against my social, cultural and historical roots. Such experiences of 'complex social relations' are best expressed by Lefebvre (1991: 18) as they made me feel 'isolated and inward-looking. I experience my individual consciousness split into two (into the private consciousness and the social or public consciousness); it also became atomised (individualism, specialisation, separation between different spheres of activity, etc.)'.

In other words, returning to the memories of my school days as an adult, I recognised this period of early schooling as one that forged a process of contradiction within me by the manner in which I was taught English, and the accompanying mannerisms, relegated my Bengali language as insignificant; it was at this stage that my bodily reaction and not my vocabulary was able to identify colonialism (Fanon 1967: 61).

With the passage of time, I became acquainted with the above-named terms, and gradually understood that the much sought after English-medium school functioned as a laboratory for manufacturing colonial forms of thinking, which acknowledge and celebrate the ideologies of British colonisation in an unquestioning way. As a result, I felt the need to interrogate and dismantle these British colonial forms of knowledge production in daily life, which in turn provoked an exploration of various possibilities for decolonising the everyday patterns of my own thinking, being and doing, many of which are taken up by existentialists world-wide (Thiong'o 1986; Ramose 1999; Maart 2004; Hunt \& Holmes 2015; Gordon 2020).

Scholars concerned with self-examination and self-interrogation as part of a continuum of consciousness raising (Maart 2006: 84) have to undertake habitual decolonial exercises; these are crucial to any form of unpacking as a scholar takes charge of the process and accepts that decolonisation begins 
with the examination of the self. The scholar then has to ask, 'How do I decolonise myself?' It is important to overcome the existential bad faith of selfcentric 'I'-ness and transcend into the collective realm of 'we'-ness, which South Africans describe as ubuntu (Ramose 1999: 32). In other words, I felt that the social, cultural, historical, political, epistemological and ontological values of my existence were shaped by the knowledge and actions of the collective socio-cultural environment in which my being was constructed. Therefore, in order to decolonise my everyday thought processes, patterns and actions, it is important to address strategies, one of which is the ability to build networks of solidarities in a transcultural and transnational manner.

It is also crucial to realise that 'there are only points of view, perspectives, masks and roles. Truth is draped in veils; it can be defined only by an endless succession of points of view' (Lefebvre 1991: 17). It is all of the above that provided me with the motivation to attend the Decolonial Summer School at the University of South Africa (UNISA) in 2017, and again in 2020. As such, in order to build pluriversal networks of solidarity and resistance against the toxic ideologies of coloniality, I ventured beyond the geographical boundaries of India, my country of birth, and took up the invitation to attend my first Decolonial Summer School at UNISA in 2017. Amidst the many agreements and disagreements, the two-week summer school at UNISA enabled me to understand the different forms of decolonial exercises that are taking place across the globe, from collective and co-creative points of view.

My understanding of decoloniality as a collaborative exercise received further impetus during the UNISA Decolonial Summer School of 2020. The week-long summer school taught me the theoretical, ideological and the phenomenological differences between 'decolonialism', 'decolonisation' and 'decoloniality' and the many ways to understand them within particular social, cultural, political, geographical and racial contexts. During the engagement with scholars in attendance, I soon realised that the terms decolonialism, decolonisation and decoloniality are not philosophical doctrines but openended, de-hierarchical and depolarised exercises whereby one shows regard for learning and also shares with others the diverse constellations of knowledge that exist across the globe. These terms also generate epistemological and ontological ambiguities as essential categories of everyday life. 'It never exhausts its reality; from the ambiguity of consciousness and situations spring forth actions, events, results, without warning' (Lefebvre 1991: 18). The urge to participate, habitually, in these ambiguous exercises motivated me to 
investigate the influence of colonisation and coloniality in everyday life. As such, I made a presentation on the burden of colonial gastronomy in colonial West Bengal at the UNISA Decolonial Summer School of 2020.

\section{Colonial Practices and Complicity}

The practice of British and Portuguese colonisation, in particular, and its effects are deeply engraved on the psyche of the colonised of past-partition contemporary India. This is seen in the way that physical appearances, body language, food customs, fashion choices and racialised attitudes towards dark-skinned Indians, our own people so to speak, are driven by the colonial social and cultural parameters created by the primary coloniser, the British, and are now perpetuated by the upper classes of India, in the name of modernity and postmodernity.

As such, the acknowledgement of colonial food customs and culinary practices in India is nothing new; the problem, however, lies in the lack of awareness. I am not opposed to, nor do I have a problem with, embracing culinary dishes from different parts of the world as I believe that it is an act of showing appreciation toward other cultures through their food. However, if North American, and a select number of European culinary practices, are promoted at the cost of delegitimising, dehumanising and diminishing Indigenous culinary practices, then it is important to probe the social, cultural, geographical, historical and racist intentions of such acts. Through the criticism of colonially fashioned habitual food customs and culinary practices in this article, 'everyday life also emerges as a critique, a critique of the superior activities in question (and of what they produce: ideologies)' (Lefebvre 1991: 87). The exercise of decolonising and deracialising the taste buds, as discussed in this article, unpacks the "value of culture as a factor of resistance to foreign domination' (Amílcar Cabral as cited in BLACKPAST 2009).

I was born into a family of chefs. My great-grandmother, my grandmother, my mother, my father, my grandfather, my great-grandfather, my uncles, my aunts and my siblings either were or are fabulous cooks. As I was born into a Bengali family, expectedly, my introduction to a broad range of food items were centred on traditional Bengali foods. I cannot deny the fact that apart from traditional Bengali food, I was also introduced to communal cuisines that can be depicted as socially, culturally and racially diverse. This introduction to a multicultural gastronomy was underlined by diverse 
narratives, which were shared and confirmed by my parents and grandparents. On the one hand, the narratives enabled me to map the evolution and development of Bengali food culture in the contemporary Indian state of West Bengal across the precolonial, colonial and postcolonial times and on the other, the narratives provoked an interest to investigate the various 'colonial and cultural forces that sought to dominate its creation and dissemination' (Chaudhury 2020: 1).

For instance, during my childhood days when I requested that my grandmother prepare a dish of chikin $c h o w^{1}$ or bhej $c h o w^{2}$, she would laugh and say: 'You should have taken birth [been born] in a Cheena bari' ${ }^{3}$ rather than in a Bengali household'. I remember how my preference for chicken over lamb was mocked by my grandparents. They would often say: 'You are [a] Muslim born in a Hindu household'. When my friends and relatives came to know that I usually have dinner between 7:30 pm and $8 \mathrm{pm}$, they would often laugh and say: 'You are born with a Bengali face and a British body'. I often wondered why it was necessary for me to be born into a Chinese household in order to enjoy eating chow mein or why preferring chicken over mutton implied that I needed to be a Muslim, or when consuming an early dinner, I was considered British?

With the passage of time, these ponderings gradually transgressed into phenomenological interrogations that provoked an analysis of the binaries of traditional Bengali cuisine as opposed to modern Bengali cuisine; authentic Bengali cuisine as opposed to inauthentic Bengali cuisine; good Bengali cuisine as opposed to bad Bengali cuisine; and precolonial Bengali cuisine, as opposed to colonial Bengali cuisine. These binaries were shaped by factors such as climate, religion, agriculture, caste, class and economy during the precolonial, colonial and postcolonial times. Therefore, the consumption of food is not only a biological exercise and a process of activating an individual's taste-buds but also a collective and collaborative exercise of understanding the social, cultural, communal, historical, political and economic tastes of different

${ }^{1}$ Chikin Chow is the colloquial Bengali way of referring to the dish 'Chicken Chow mein'.

${ }^{2}$ Bhej Chow is the colloquial Bengali way of referring to the dish 'Vegetable Chow mein'.

${ }^{3}$ Cheena Bari is a colloquial Bengali way of referring to the house of a Chinese person, usually in a mocking manner. 
communities across diverse geographical locations across time and space.

In view of the aforementioned arguments, the following segment analyses how gastronomical practices of the British and the Portuguese have:

i. disrupted the traditional food and culinary practices of the Bengali community in West Bengal;

ii. simultaneously, colonised the culinary practices of the Bengali community in West Bengal.

This article henceforth is divided into four sections:

1. The first section, titled 'Precolonial Food Culture of Bengal' reflects upon the different food and culinary practices of precolonial Bengal and various social, cultural, caste, communal, geographical and climatic factors that have shaped such practices.

2. The second section, titled 'Colonial Influence on Food Customs' explores the various ways through which the traditional food culture in precolonial Bengal was disrupted, dehumanised and colonised by the physical forces of British and Portuguese colonisation and later by the metaphysical forces of American capitalism in the postcolonial era.

3. The third section, titled 'Decolonising and Deracialising Taste Buds: The Aesthetics of Taste' outlines the various possibilities through which the burden of the colonial gastronomy can be dismantled and decolonised in contemporary West Bengal.

4. The final section, 'Not Exactly a Conclusion', thematically and theoretically justifies how this article does not conclude with a definite set of solutions; but rather opens up diverse decolonial possibilities for dialogues, polylogues, agreements and disagreements on re-locating and re-indigenising the traditional food customs of West Bengal in the contemporary era.

\section{Precolonial Food Culture of Bengal}

History allows us to know the nature and extent of the imba- 
lances and conflicts (economic, political and social) which characterise the evolution of a society; culture allows us to know the dynamic synthesis which has been developed and established by social conscience to resolve these conflicts at each stage of its evolution, in the search of survival and progress (Amílcar Cabral as cited in BLACKPOST, 2009).

In a similar manner, the precolonial food culture not only reflects upon the availability of food materials and culinary practices, but also on the diverse patterns of consumption and its aesthetic values, as detailed in different socioreligious texts. The history of food customs and culinary practices of precolonial Bengal also functions as a reminder of the persistent 'neo-colonial' relations' of the present with the past 'within the 'new' world order' (Bhabha 1990: 6). The food culture of precolonial Bengal was determined by climatic, geographical, aesthetic and socio-religious factors.

\section{Machey Bhaatey Baangali}

The Bengali phrase',Machey bhaatey Baangali' can be loosely translated as: 'a Bengali cannot live without fish and rice'. This phrase is ambivalently used in contemporary expressions among its community. On the one hand, the phrase is used as a reminder of cultural rootedness by and for the Bengalis and on the other hand, to ridicule the culinary chauvinism of the Bengalis. If, however, the origin of this phrase is socio-historically and phenomenologically investigated, then it can be said there lies a firm geographical and scientific basis behind its origin. Bengal has always been renowned for its fertile land and the cultivation of paddy rice (Arendt \& Zannini 2013: 121). The rivers of Bengal also serve as a reservoir for varieties of freshwater fish, and as a result, traditionally, rice and fish emerged 'as the staple food of the Bengalis' (Halder 2016).

It is, however, important to note that rice and fish are not the 'only' authentic food of the Bengalis. Apart from rice and fish, precolonial Bengal has been known for various non-vegetarian and vegetarian dishes. Quite unfortunately, the capitalist forces of reckless profiteering in postcolonial West Bengal have exoticised and tokenised the traditional food culture of precolonial Bengal through universally projecting the state as a manufacturing ground for rice and fish. 
As such, the global notion of Bengali cuisine is limited to a set platter, which is often and incorrectly designated as an 'authentic Bengali platter'. Within the said platter, there will be a specific vegetable dish, a fish dish, a lentil dish, a meat dish and a sweet dish. Such dishes have been carefully selected and authenticated in such a manner by Bengalis who have prepared them for centuries that it not only seduces the taste-buds, but as a result also generates a strong profit-making market space. During the era of precolonialism and pre-capitalism, when taste-buds were not dictated by the market, geographical conditions aside, the dietary practices in precolonial Bengal were widely influenced by climatic conditions.

\section{Shukhrobarer Sondhey belaye Esho Money Rekhe/Doodh Chere Prothom Ami Khabo Bhaat Mekhey}

The above-noted phrase is taken from an invitation card for Annaprashan ${ }^{4}$. Annaprashan is referred to as the first rice-eating ceremony. The phrase can be loosely translated as: on a Friday evening, you are warmly invited to my first rice-eating ceremony. Usually, in West Bengal the rice eating ceremony takes place in the evening during which guests are invited to partake in the first riceeating ceremony of a one-year old child over dinner. In India, the rice eating ceremony is celebrated when a one-year old child finishes the breastfeeding period and gradually moves towards the weaning period. The onset of the weaning period is celebrated through the rice eating ceremony. In the ceremony, the gathering is usually organised over dinner instead of lunch as determined by the hot and humid climate of the state. If the ceremony takes place during the summer season, then the hot and humid weather during the day makes it challenging for people to participate in a public gathering. During the evening, the heat and the humidity subsides and as a result the process of gathering becomes more comfortable, as compared to hosting the event during the day.

Apart from the gathering time, one might ask: Why is it always a riceeating ceremony and not a bread-eating ceremony or perhaps even something else? Two major factors underlie this traditional practice - that is, the socioreligious and climatic considerations. According to a Bengal government report of the 1940s, the weather conditions demanded the daily requirement of

\footnotetext{
${ }^{4}$ Anna means rice; Prashan means eating.
} 
3600 calories per person, for the entire population of precolonial Bengal and rice played a pivotal role in ensuring the supply of these calories (Murshid 2008: 483).

Chitrita Banerji in Life and Food in Bengal (2005) notes that around '3500 calories are acquired from rice itself' (Banerji 2005: 76). Besides the consumption of boiled rice, different varieties of rice were also consumed like muri (puffed rice), khoi (flattened rice), and so forth. The high calorie content of rice enables the individuals to cope with health problems such as diarrhoea and dehydration which can be caused by extreme heat and humidity. This practice also interrogates the Western science of modern food, which are widely mimicked in India today. In an article titled 'Weight Loss Secrets: 5 Things You Should Never Eat at Night' (2015), the author notes: 'White rice is just as bad as white bread; in addition, it also has very little nutritional value'. The above-mentioned government report has already proved that this argument is baseless in the contemporary era. Different types of food practices are adopted according to the geographical, climatic, social, religious and economic conditions of a particular place. Therefore, the universalised narrative of 'ideal and healthy food' as propagated by Western science is highly questionable.

\section{Charbya-Choshya-Lehya-Peya}

This sub-section of the article unpacks the socio-religious factors that influenced the precolonial food customs of Bengal. According to Pranad Ray in Banglar Khabar (1987) and Bipradas Mukhopadhyay in Pak Pranali (2007), charbyaare the foods that are consumed by chewing, such as rice (bhaat), meat (mangsho), vegetables (shobji), fish (maach), and so forth; choshyaare the foods that are consumed by sucking such as homemade digestive enzymes (homemade probiotic drinks that are made with fruits and spices) popularly known as ambal, tak; lehya are the foods that are consumed by licking such as chatni (chutney), payesh (sweet porridge), doi (yoghurt); and peya are the foods which are consumed by drinking, such as milk and juice.

In, The Vishnu Purana ${ }^{5}$ (Parashara 2015). a definite sequence of eating has been prescribed: 'meals should start with the sweet dish, followed by salty dishes and end with spicy and bitter dishes' (245). One of the major reasons

${ }^{5}$ The Vishnu Purana is one of the eighteen ancient and medieval texts of Hinduism. 
behind prescribing such a sequence is that the habit of eating sweet dishes at the beginning and eating bitter dishes at the end eases the process of digestion and guards the stomach against bacterial infections. The Brihad-dharma Purana (1915) proposes a different sequence: ' ... boiled rice and ghee should be consumed first, followed by spinach and rest of the vegetables, and the meal should end with milk and boiled rice' (translated by Banerji 2005: 185). The Bengali author saw his grandfather following a similar eating pattern as outlined in Brihad-dharma Purana: he begins his lunch with boiled rice and ghee and ends it with milk and boiled rice. One day, out of curiosity, I asked him why he finishes his lunch with milk and boiled rice on a daily basis? $\mathrm{He}$ replied, that a vegetarian meal should always consist of milk and boiled rice because they are sources of protein, calcium and energy. These also supplement the meat, fish and/or egg in a non-vegetarian meal. It should also be consumed at the end of a vegetarian meal because it protects the body against health problems such as gastroenteritis and acidity.

According to Prakritapaingala, a 13th century collection of verses in Bengali by Pingalacharya, an ideal Bengali platter should consist of 'mainimaccha lection of verses in Bengali by Pingalach' (cited in Banerji, 2005: 23). In other words, that it should consist of hot rice with ghee, leaves of the jute plant that are prepared by frying and hot milk. Sriharsa's writing, The Naishada-Charitaor the adventures of Nala Raja of Naishada (1836), a 12th century Sanskrit epic, provides a detailed insight into the Bengali eating culture through the marriage of the protagonists called Nala and Damayanti:

At their wedding feast, different dishes are served, such as cooked vegetables, fish, mutton, deer meat, different varieties of pitha (a sweet variety), flavoured drinks and tambul (betel leaves) (Sriharsa 1836: 450).

The Brihad-dharma Purana also mentions the caste-based food of precolonial Bengal. For example, the Brahmins, the upper caste who were notably priests and rulers, widely consumed white-scaled fish like ruhi (carp), punti (barb) and shakul(salmon) because white-scaled freshwater fish were considered spiritually pure and healthy; the Kshatriyas, one of the four varna, or social castes that occupied a position on the hierarchy below the Brahmins, and were composed of warriors and rulers, preferred a meat-based diet of poultry, venison, lamb, and so forth because socio-culturally the consumption of meat 
was associated with masculine power and warfare; the Vaishyas, one of the four castes that occupied a lower position on the hierarchy after the Kshatriyas, composed primarily of businessmen and traders, preferred a vegetarian diet because their indulgence with trade and commerce provoked dietary purity and spirituality (Dhillon 2014; Agarwal 2016; Waghmore 2017).

In India, generally, dietary purity and spirituality are associated with a vegetarian diet. The Sudras, also known as the outcasts, considered the lowest of the four varnas of the Hindu caste system were regarded as scavengers and it was believed that because of their outcast status they were generationally condemned to live on rotten meat (Doctor 2008; Samal 2017). Tikasarvasvaby Sarvananda sheds light on the socio-cultural differences within the food customs of precolonial Bengal by specifically showing 'the love and passion of the people of east Bengalis for shuktimachh (dried fish)' (cited in Ray 1987).

Even today, shutkimach stands as an epitome of Bengal ${ }^{6}$ culture. Tikasarvasva also mentions some of the spices that were habitually used in the precolonial traditional Bengali kitchen such as marich (black pepper), labanga (clove), jirak (cumin), ada (ginger), jaifal (nutmeg), hing (asafoetida), etc.

Mukundaram Chakravarti in Kabikankan-Chandi (Chandimangal) (2011) notes how in medieval Bengal, irrespective of caste, class or regional differences, vegetarian dishes were blended with non-vegetarian dishes. For example, chingri maach die cholar daal (lentils cooked with prawns), chital maach die palang-er chocchori (chital fish cooked with spinach), machher matha die puisaaker chocchori (basella leaves cooked with fish head), fulbori die macher jhol (lentils cooked with fish), chingri die borar jhol (prawns cooked with a type of lentil fritter), thod chingri(prawns cooked with thod (a type of vegetable)), etc. It is also important to note that this amalgamation of vegetarian and non-vegetarian dishes was typically practised by the local residents of the Medinipur district of precolonial Bengal. Although it is widely consumed by the people all across the state, it was adopted from the food culture of those in Medinipur. In Bharatchandra Ray's 'Annadamangal' around 23 types of vegetarian and non-vegetarian dishes are mentioned:

... sarsadi, ghanta, different types of fried spinach, thick soup of gram pulse, arahad, moong, mas, barbati, batul, and matar dal, bada, badi,

${ }^{6}$ Bangal is the colloquial Bengali term, which is used to refer to the original residents of the eastern part of Bengal. 
banana, radish, coconut fry, milk and dalna prepared with thod, shuktoni, jackfruit seeds with sugar, bottle-gourd with til and pithali, brinjal, and preparations of pumpkin. Among the non-vegetarian dishes were katla, fried chital fish, koi, magur and shol fish, boiled turtle egg (ganga fal) and the various meat preparations like shikpora (meat burnt in a spit, later known as kabab). Apart from these dishes there were some other unconventional dishes such as preparations with bamboo flower, and dalkachu and odkachu ${ }^{7}$ (cited in Bose 2004: 355 - 357).

These food practices of precolonial Bengal underwent a massive transformation with the invasion of Islamic rulers during the $18^{\text {th }}$ century. On the one hand, the invasion introduced several new food items like 'watermelon, pomegranate, pulao $^{8}$, biriyani ${ }^{9}$, kabab $^{10}$, kofta $^{11}$ and kaliya ${ }^{126}$ (Halder 2016) and on the other hand, the already existing caste and class divisions were further fractured. Prior to the Islamic invasion, onion and garlic, either in cooked or raw form, were hardly consumed by the Bengalis - certainly not by the Brahmins. However, after the arrival of the Muslims in precolonial Bengal, with the passage of time, onion and garlic were introduced as a daily cooking ingredient in the Bengali kitchen. While the Hindu outcasts, the Sudras, voluntarily adopted the new food practices as propagated by the Muslims, the Brahmins, the Kshatriyas and the Vaishyas firmly resisted the Islamic food practices and strictly prohibited the consumption of their food items. The former also believed that 'the smell of prohibited food could lead to degradation of caste status or expulsion from the religious community' (Halder 2016).

\section{${ }^{7}$ Types of arum roots.}

${ }^{8}$ This dish is prepared either with meat (and sometimes fish) or vegetables and rice. Different varieties of vegetables or meat are fried; spices are added and then mixed with boiled rice. At the end ghee is added for flavor.

${ }^{9}$ This is a rice dish which is prepared by mixing meat, rice, potato and boiled eggs. Unlike polau, where the ingredients are prepared separately and then mixed at the end, Biryani is a one-pot meal and it is prepared by putting all the ingredients together in one pot.

${ }^{10}$ A spicy grilled meat dish.

${ }^{11}$ Koftas are fried balls either prepared with meat or vegetables.

${ }^{12}$ Either prepared with fish or meat, Kaliya is a spicy gravy, which is usually served with rice. 
There was a time when the consumption of chicken and beef was strictly prohibited in the upper-caste Bengali households because it was incorporated into the mainstream Bengali cuisine by Muslims. An upper-caste Bengali was strictly forbidden to consume any kind of food items that had been touched and/or prepared by a person of Muslim faith. A violation of such a norm resulted in familial or community expulsion. As a consequence, my grandparents laughed at my fondness for chicken. In addition, my friends questioned my Hindu identity when they learnt of my fondness for beef kebab and beef kofta. According to Ghulam Murshid in Hajar Bacharer Bangali Sanskriti (2008), apart from the Hindu outcasts, the Islamic food culture was adopted by the Bengali middle-class Hindus and the high-class Hindus who converted to Islam (Murshid 2008: 491 - 492). These fragmentations in the food customs and culinary practices gave rise to multiple forms of social, cultural, communal, class and racial hierarchies.

\section{Panch Phoron}

Panch Phoron is a spice that has been an integral part of precolonial Bengali cuisine. The term Panch Phoron can be translated into English as 'a combination of five spices'. Usually, the five spices are: nigella seeds (also known as black cumin or kalonji), fenugreek seeds, cumin seeds, black mustard seeds and fennel seeds. It is very difficult to trace the historical evolution of the concept of panch phoron, but it is believed that the combination of five spices has a spiritual and mythical significance with the number five as mentioned in 'Rig Veda'. In 'Rig Veda', 'the number five may be related to Pancha Bhoota, which is the basic five elements that Hindus claim is the basis of creation. Those elements are fire, water, air, earth and ether' (cited in 'Panch Phoron: Indian Five-Spice' 2020). In the traditional Bengali households, the ingredients of panch phoron were thus associated with the Hindu religious notion of Pancha Bhoota. Therefore, in precolonial Bengal the use of panch phoronin daily food dishes was not only considered healthy but was also used in the cooking of food items during the religious rituals. With the Islamic invasion of Bengal, the binaries between 'authentic Hindu foods' and 'authentic Muslim foods' started developing (approximately during the 18th century), and as a result panch phoron became a medium for preserving one's 'pure Hinduness' in the Bengali households. It was also regarded as an apt 
substitution for garlic and onion, the consumption of which was believed to be strictly against the Hindu spiritual values. Even today, panch phoron is a common spice in the Bengali cuisine.

The Bengali author recollects, two specific panch phoron delicacies from his grandmother's and mother's kitchen - aloo panch phoron and panch phoron die musur daal. Aloo panch phoron is prepared with boiled potatoes (aloo), mustard oil, salt, panch phoron and turmeric powder. Besides, aloo panch phoron another delicacy that is highly appreciated in the Bengali author's family is panch phoron die musur daal. Musur daal, also known as red lentils, are cooked with mildly fried panch phoron, salt and turmeric powder. The usurpation and settler colonial presence of the British colonisers gave rise to pseudo-scientific and pseudo-medical narratives, which declared the consumption of panch phoron unhygienic and unhealthy in the tropical weather conditions (U. Ray 2012: 710).

The imposition of these illogical perspectives widened the already existing class, caste, gender, communal and economic hierarchies in precolonial Bengal's culinary practices. It also opened gateways for the British colonisers to deculturalise and dehumanise the traditional gastronomic practices of precolonial Bengal in a very systematic manner, relying on what they were able to do best - divide and rule.

\section{Colonial Influence on Food}

Valentin-Yves Mudimbe in his book titled, On African Fault Lines: Meditations on Alterity Politics. Thinking Africa argues:

The colonial library is a transdisciplinary space that for centuries transcended axes of separation between natural and social sciences. Its huge knowledge capital was put to the service of absolute aberrations such as the slave trade. The library justified the unjustifiable in deviant ethics, shaming human intelligence (Mudimbe 2013: 19).

The process of animalisation and subordination of food /customs and culinary practices of precolonial Bengal and the appropriation of colonial food ethics played a crucial role in not only justifying the unjustifiable logic of the tropical climatic conditions and the behavioural patterns of the local residents of precolonial Bengal, but also in generating a set of archives that turned to the 
past of the oppressed people, and distorted, disfigured and destroyed it (Fanon 1963: 71). In Black Skin, White Masks (1967), Frantz Fanon notes that 'A man who has a language consequently possesses the world expressed and implied by that language' (Fanon 1967: 59). So apart from trade, commerce, politics and slavery, food functioned as an effective 'language' for the British colonisers to build their physical and ideological empires in precolonial Bengal. However, their process of gastronomic colonisation involved seduction as well as coercion. Seduction's reward was the false promise of recognition by the master. It is believed that the British in India tried to convince the Natives that if the colonised in India chose the British way, they would have the reward of being seen as British, and therefore more civilised.

In order to establish mercantile relationships with India, European ships began to arrive on the Indian shores from the late 15th century. Historical documents reveal that the Portuguese were the first to reach the Indian subcontinent and they were gradually followed by the Dutch, French, Danish, and the British. As the Portuguese arrived, apart from the various precious items they stole from the continents of Africa and the Americas, they brought along with them several new food items, either vegetables or 'processed' food such as 'potato, chili pepper, okra, tomato, cauliflower, cabbage, bread, cheese, jelly and biscuits' (Sen 1997: 95; Habib 2014: 54 - 60).

In the article 'The Portuguese Influence on Bengali Cuisine' (1997), Collin Taylor Sen outlines a detailed table of the different fruits and vegetables that were brought to Bengal by the Portuguese and later on, how these became part of the regular Bengali cuisine from the colonial era. We cite it here to foster further discussion of our main argument:

\begin{tabular}{|l|l|l|l|}
\hline $\begin{array}{l}\text { English } \\
\text { Name }\end{array}$ & $\begin{array}{l}\text { Bengali } \\
\text { Name }\end{array}$ & Comments & $\begin{array}{l}\text { Use in } \\
\text { Bengali } \\
\text { Cuisine }\end{array}$ \\
\hline Cashew & Kaju & $\begin{array}{l}\text { Native of S.E. Brazil, introduced } \\
\text { to the west coast of India to } \\
\text { check soil erosion. Today India } \\
\text { is the world leader in its } \\
\text { production. }\end{array}$ & Snacks. \\
\hline
\end{tabular}




\begin{tabular}{|c|c|c|c|}
\hline Pineapple & Anaras & $\begin{array}{l}\text { Introduced in Bengal in } 1594 \\
\text { from Brazil. }\end{array}$ & $\begin{array}{l}\text { Used fresh } \\
\text { in chutney. }\end{array}$ \\
\hline Peanut & $\begin{array}{l}\text { Chinar } \\
\text { Badam }\end{array}$ & $\begin{array}{l}\text { Introduced from America, } \\
\text { perhaps via Africa. The Bengali } \\
\text { name means 'Chinese nut' which } \\
\text { indicates that it could have } \\
\text { arrived via Manila or China. } \\
\text { However, 'Chinese' is also an } \\
\text { adjective used by Bengalis to } \\
\text { denote anything foreign. }\end{array}$ & Snacks. \\
\hline Papaya & Peypey & $\begin{array}{l}\text { Originated in Central America. } \\
\text { Came to India via Philippines } \\
\text { (where the Spanish had taken it) } \\
\text { and Malaysia. }\end{array}$ & $\begin{array}{l}\text { Unripe as } \\
\text { fruit, paste } \\
\text { used as a } \\
\text { meat, } \\
\text { tenderiser. }\end{array}$ \\
\hline $\begin{array}{l}\text { Sweet } \\
\text { Potato }\end{array}$ & $\begin{array}{l}\text { Ranga } \\
\text { Aloo }\end{array}$ & $\begin{array}{l}\text { Introduced from Africa or } \\
\text { Brazil. Bengali name means 'red } \\
\text { potato'. }\end{array}$ & $\begin{array}{l}\text { Used as a } \\
\text { vegetable, } \\
\text { used in } \\
\text { sweet dishes } \\
\text { to add } \\
\text { flavour and } \\
\text { in shrimp } \\
\text { dishes. } \\
\end{array}$ \\
\hline Potato & Aloo & $\begin{array}{l}\text { The Spanish brought the first } \\
\text { potatoes to Europe in } 1570 . \text { On } \\
\text { the west coast of India, it is } \\
\text { called batata (sweet potato). In } \\
1780 \text {, a basket of potatoes was } \\
\text { presented to Sir Warren } \\
\text { Hastings in Calcutta (Achaya } \\
\text { 1991: 118). It was grown in the } \\
\text { foothills of the Himalayas in the } \\
\text { 1830s. By 1860, potatoes had } \\
\text { become popular in Calcutta, } \\
\text { although orthodox people } \\
\text { avoided them until the 20th } \\
\text { century. }\end{array}$ & $\begin{array}{l}\text { Vegetable } \\
\text { dishes, dried } \\
\text { and with } \\
\text { gravy; in } \\
\text { shukto, } \\
\text { poshto. In } \\
\text { curries with } \\
\text { meat and } \\
\text { seafood. } \\
\text { Filling for } \\
\text { samosas. }\end{array}$ \\
\hline
\end{tabular}


Decolonisation and Food: The Burden of Colonial Gastronomy

\begin{tabular}{|l|l|l|l|}
\hline Tomato & $\begin{array}{l}\text { Bilayati } \\
\text { Begun }\end{array}$ & $\begin{array}{l}\text { Originated in Mexico or Peru. } \\
\text { Came via England in the late } \\
\text { 18th century }\end{array}$ & $\begin{array}{l}\text { Chutney. } \\
\text { Flavouring } \\
\text { for lentils }\end{array}$ \\
\hline Chillies & Lanka & $\begin{array}{l}\text { The Bengali name indicates it } \\
\text { may have come via Sri Lanka. } \\
\text { Originated in Central America. } \\
\text { Spread rapidly in India as } \\
\text { substitute for long or black } \\
\text { pepper. By the mid-16th } \\
\text { century, Europeans were calling } \\
\text { it 'Calcutta pepper.' }\end{array}$ & $\begin{array}{l}\text { Fresh, dried, } \\
\text { and } \\
\text { powdered. } \\
\text { Used for } \\
\text { flavouring } \\
\text { and } \\
\text { decoration. }\end{array}$ \\
\hline $\begin{array}{l}\text { Guava } \\
\text { Peyara }\end{array}$ & $\begin{array}{l}\text { May have originated in Peru. } \\
\text { Known in Eastern India as early } \\
\text { as 1550. Widely grown in } \\
\text { Bengal. }\end{array}$ & $\begin{array}{l}\text { Eaten as } \\
\text { fruit, Guava, } \\
\text { cheese and } \\
\text { jelly. }\end{array}$ \\
\hline $\begin{array}{l}\text { Corn or } \\
\text { Maize }\end{array}$ & Bhutta & $\begin{array}{l}\text { Originated in Central America. } \\
\text { Finger }\end{array}$ & $\begin{array}{l}\text { Roasted and } \\
\text { eaten on the } \\
\text { cob, usually } \\
\text { purchased } \\
\text { from street } \\
\text { sellers. }\end{array}$ \\
\hline Litchi & Lichu & $\begin{array}{l}\text { Native to southern China. The } \\
\text { Portuguese brought it to Bengal } \\
\text { at end of the 19th century. }\end{array}$ & $\begin{array}{l}\text { Eaten as a } \\
\text { fruit, juice, } \\
\text { jelly and } \\
\text { drunk as } \\
\text { wine. }\end{array}$ \\
\hline $\begin{array}{l}\text { Probably from Africa } \\
\text { or cooked in } \\
\text { stews. }\end{array}$ \\
\hline
\end{tabular}

Beside fruit and vegetables, many other food items like biscuits and baked pastries were introduced by the Europeans, particularly the British. K.T. Achaya in 'The Food Industries of British India' (1991) talks about a famous French traveller, Francois Bernier who visited Bengal in 1660 and in one of 
the memoirs Bernier mentions that 'the supply of inexpensive biscuits to the crews of European ships was very common' (Achaya 1991:123). This confirms the widespread belief that small-scale biscuit manufacturing units had already developed in Bengal in the 17th century.

Apart from biscuits, the introduction of cheese by the Portuguese brought a major transformation to the traditional culinary practices of Bengal. Several new food items like chhanar dalna (cheese ball curry), potoler dolma (pointed gourd stuffed with cheese), rosogolla (cheese balls soaked in sugar syrup), pantua (deep-fried cheese balls soaked in sugar syrup), lyangcha (cylinder-shaped fried cheese soaked in sugar syrup), sukto (assorted vegetables along with bitter gourd cooked in milk and poppy seeds), chhanar payesh (rice cooked in cheese, milk and jaggery) and so forth, evolved in the traditional Bengali kitchen.

The regular use of cheese in the Bengali kitchen changed the place of desserts under the influence of the Portuguese in colonial Bengal. Today, all the cheese-based sweet dishes that are consumed in West Bengal are as a result of Portuguese colonialism. Other than the Portuguese, the French colonisers widely influenced the snack culture of Bengal. For instance, the concept of mamlet was drawn from the French omelette. Usually, a French omelette is prepared with eggs, milk, salt, black pepper, unsalted butter and a filling of crème fraiche, herbs, fresh fruits, and so forth. However, a mamlet in West Bengal is prepared with eggs, salt, chopped onions, chopped chillies, chopped tomatoes, garam masala and oil. Unlike the French omelette, mamlets are made without any filling. Of interest is that the Dutch and the Danish did not have much influence on the food culture of Bengal.

With the arrival of the British, the already transformed food culture of Bengal under Portuguese colonisation underwent further transformation and it had a mixed impact on the local population. In precolonial Bengal, 'Bengali cuisine not only refused to become national, but by remaining emphatically regional, its domestic nature was also kept intact' (Ray 2012: 705). During the period of colonial Portuguese occupation, the regional essence of the food and culinary practices did not change, rather it was multiplied and diversified because, like the British, they did not enforce their food on the local Natives of Bengal. Rather, they acknowledged the amalgamation of Portuguese culinary practices with the local culinary practices in the Bengali kitchen.

The introduction of British food customs in tropical Bengal were underlined with the expropriation of local food and the appropriation of British 
culinary practices. This process of expropriations and appropriations was catapulted by the 'colonial medical texts from 1770 until at least 1850' (Sengupta 2010: 82). The tropical climate of Bengal raised the fundamental question: is the heavy meat-based diet of the British suitable in such weather conditions? The British displayed 'a kind of false bravado, and the exhibition of a generous contempt for what they reckon[ed to be] the luxurious and effeminate practices of the country' (Curtis 1807: 280). Such a false bravado motivated the British colonisers to blame the climate for their afflictions, rather than the unsuitability of their diet. In 1775, Philip Francis, the Governor of Bengal wrote: 'I am tormented with the bile and obliged to live on mutton chop and water. The Devil is in the climate I think' (cited in Burton 1993: 7). Disapproving colonial sentiments steeped in Christianity were not an unfamiliar basis of critique by the British of India; the British not only believed that God was on their side as they usurped, colonised and plundered, but when God was not, the devil had to be held responsible (Maart \& Dey forthcoming).

Elizabeth Collingham in her book titled Imperial Bodies: The Physical Experience of the Rajc.1800-1947 (2001) argues that such unhealthy dining 'served well to underline the status of the Company grandee in India' (Collingham 2001:75-77). Collingham also argues that through the racialisation of Bengal during and after the Indian Revolt of 1857 the 'body of the British official in India became an even more powerful signifier of "Britishness", and diet and dress became, accordingly, cultural sites on which a sense of bodily difference between the British and their Indian subjects were maintained' (81 - 84). It is evident from John Beames' Memoirs of a Bengal Civilian (1961) in which he talks about the daily food of a British official in the late 19 th and early 20 th centuries. He notes:

Our chota haziri, or little breakfast, was at five-thirty to six, and consisted of tea, eggs boiled or poached, toast and fruit ... Breakfast at eleven consisted of fried or broiled fish, a dish or two of meat generally fowl cutlets, hashes and stews, or cold meat and salad followed by curry and rice and dessert. We drank either bottled beer - the universal Bass - or claret ... Between four and five there was tea and cakes, ... Dinner at half past seven or eight consisted of soup, and entrée, roast fowls or ducks, occasionally mutton, and in cold weather once or twice beef, and entremets of game or a savoury, and sweets (Beames 1961: 197). 
In the tropical heat and humidity of Bengal it does not require any medical books or scientific experiments to justify that such a food routine is lethal to the body. In the year 1807, even a British surgeon from the naval hospital of Madras named Charles Curtis observed that the 'over-consumption of meat was the root of many of their ills' (Curtis 1807: 280). He also noted: 'They cannot too soon ... accustom themselves to what are called the native dishes, which consist for the most part of boiled rice, and fruits, highly seasoned with hot aromatics, along with meat item[s] and sauces, but with a small proportion of animal matters' (Curtis 1807: 281). As such, Dipesh Chakrabarty in Rethinking Working-Class History. Bengal 1890 - 1940 (1989) rightly suggests that 'eating was a ritualised expression of a colonial ruling-class culture ... signifying ... excess and plenitude' (Chakrabarty 1989: 167).

The signifiers of excess and plenitude gradually percolated into the food and culinary practices of the upper and middle class Bengali community through the usage of spoons and forks instead of hands, through the pleasure of wasting food items instead of re-using them, or sharing with others, through risking one's health by blindly mimicking the European (especially the British) culinary practices, etc. 'It is not that the Europeans were not aware of the non-suitability of their dining, but to maintain their superior status of "Europeanness or Britishness", through food, they continued to practice "brutal racialisation" and "abusive adjectivisation" (Dey 2020a).

Besides naturalising such a dietary practice as 'authentic and healthy', the British also used food as a medium to assert their White masculine superiority over the local Natives. As a result, several cookbooks that were published during the period of British colonisation in Bengal portrayed the kitchen and the food items as 'filthy, dirty and uncouth' (Sengupta 2010: 85). Arthur Kenny-Herbert Wyvern's cookbook Culinary Jottings: A Treatise in Thirty Chapters on Reformed Cookery for Anglo-Indian Exiles (1885) describes the local Bengali kitchen in the following manner: 'a wretchedly mean, carelessly constructed, go down [outbuilding] ... inconveniently far from the house, and consequently open to every passer-by' (Wyvern 1885: 499). The author also criticises the presence of inadequate equipment in the kitchen, noting that 'the cook had to use his cloth for a sieve, and his fingers for [a] spoon or fork' (Wyvern 1885: 499). Another cookbook titled Indian Outfits and Establishments: Practical Guides for Persons to Reside in India (1882) characterises the Native food and culinary styles of Bengal as: 'the native ways are not as our ways and the less you see them over their cooking 
operations the more appetite you will have for the food set before you' (Wyvern 1885: 68).

It is important to note that the traditional Bengali kitchen was always open to the passer-by because it was not just a private family space to prepare food, but also a welcoming public space to feed a hungry passer-by. This had been an integral part of the traditional culture of precolonial Bengal. The British disapproved of, and rejected, this traditional custom and through the assistance of White European medical men they tried to highlight the perceived degenerated culture of the Bengalis. James Ranald Martin, a presidency surgeon of Bengal who later became the president of the East India Company's Medical Board, in his book Notes on the Medical Topography of Calcutta (1837) reflected:

When we reflect on the customs of the natives, their long misgovernment, their religion and morals, their diet, clothing, etc., and above all their climate [e.i.o] we can be at no loss to perceive why they should be what they are (Martin 1837: 43 - 45).

Justifications for colonisation and subordination were inserted everywhere, especially medical journals. If the British could sustain their argument, in writing, of the colonisation of India as a necessity, in the name of goodwill and modernity through which they depicted themselves as saviours of the savages, they could justify the extraction of wealth and the brutal exploitation of the Indian population ((Palates of Pleasure, Maart \& Dey forthcoming).

In accordance, the disputed thread between food, masculinity climatic conditions and medical science was further entrenched by the 18th century theories of climatic determinism as discussed by Thomas R. Metcalf in Ideologies of the Raj (1994): 'heat and humidity were seen as conspiring to subvert manliness, resolve and courage' (105). Sir Herbert Risley in The people of India (1908) and Robert Orme in Of the Government and People of Indostan (1971) justify that effeminacy of the people of colonial Bengal are directly associated with their 'enfeebling diet' $(42-45,57)$ and habit of consuming 'easily digestible' $(47,58)$ food such as rice, lentils, sweets and spices. Such problematic narratives received further applause from the highcaste and middle-class Bengali Hindus.

The colonised high-caste and middle-class Bengalis supported such food narratives because it catered to their taste-buds on the one hand and 
enabled them to 'be in the good books' of the British colonisers on the other. It allowed them to equate these food narratives with civility and modernity, and to show how much, they as the high caste, had in common with the British. Authors like Pragnasundari Devi and Rwitendranath Tagore felt that the traditional food and culinary culture of precolonial Bengal were narrowly defined. Buddhadeb Basu, in his book Bhojan Shilpi Bangali (2004) defines Bengali cuisine as, 'liberal and cosmopolitan, with the potential to incorporate all other flavours and indigenise them, so representing a synthesis of different cultures' (Basu 2004:18).

The support of the high-caste and the middle-class Hindus encouraged the British to use gastronomic narratives as a tool to practice social, cultural, communal, racial, caste and religious-based divisions in colonial Bengal and reduce the traditional food of precolonial Bengal into a 'disruptive, decivilising, dehumanising, exploitative, racist, violent, brutal, covetous and thingifying system' (Cesaire 2001: 71). So, instead of becoming a synthesis of different cultures, the culinary practices of Bengal, under British colonisation, gradually became a glorification exercise of the European food culture, supported by the upper caste Brahmins (U. Ray 2012: 715).

The traditional fried cheese-based sweet dishes, widely adapted from the Portuguese, such as lyangcha, Lady Kenny (round shaped shallow fried cheese balls soaked in sugar syrup) and pantua and chhana bhaja (fried cheese) lost its popularity and was replaced by pastries and baked goods because the black and blackish-brown colour of these traditional sweet dishes made the Bengalis believe that it would darken their skin. They believed their skin would become much darker, which as a result of the 'divide and conquer' strategies of British colonisation that entrenched skin colour hierarchies, had to be avoided. In the postcolonial era, the dehumanisation and subalternisation of traditional food customs of precolonial Bengal aggravated by the Americanisation and commercialisation has a significant effect on individual taste buds.

Today, a large number of people in West Bengal believe that the traditional food customs of precolonial Bengal are 'unmodern' and 'backdated' and in order to develop a cross-cultural and universal food habit one must blindly adhere to the 'European or widely Euro-North American (USA) food practices such as pizzas, pastas, burgers, sandwiches, Tacos, a Mexican food item, different forms of salads, consumption of varieties of meat, etc.' (Dey 2020a). 
There is nothing morally wrong with inculcating new tastes; but intentions are important as they more often than not speak to cultural appropriation and cultural imperialism. The practices of cultural imperialism in India (especially in precolonial Bengal) enabled the White European colonisers to disguise themselves under the existential patterns of the Black Natives. Such a form of disguise allowed the colonisers to generate seductive narratives of Western/ colonial superiorities and non-Western/ Indigenous/Native inferiorities. These narratives provoked the local Natives of Bengal to expropriate the Indigenous socio-cultural practices and appropriate the practices of the European colonisers in a voluntary manner.

This is why, the European colonisers through the 'so-called theory of progressive assimilation of native populations' (Amílcar Cabral as cited in BLACKPOST 2009), could successfully colonise the food and the culinary practices of the Natives of precolonial Bengal by camouflaging themselves as welfare workers and progressive settlers. European and North American food have further augmented the already existing racial, class and caste hierarchies that existed in precolonial and colonial Bengal. As a result, in the process of trying to be a local citizen, the adaption of such food has decapitated the Indigenous socio-cultural sense of belonging of people in contemporary West Bengal.

In order to counter the colonial/capitalist invasions of European and North American food and culinary practices in contemporary West Bengal and to revive the traditional precolonial food cults, multiple initiatives are being undertaken by individuals, government institutions and private institutions, which will be discussed in the following section.

\section{Decolonising and Deracialising Taste Buds: The Aesthetics of Taste}

The process of challenging, countering and dismantling the colonial and capitalist invasions of European and North American food and culinary practices is what Lewis Gordon argues as a movement from 'double consciousness to potentiated double consciousness' (Gordon 2014). In other words, double consciousness can be understood as 'seeing yourself through the hostile other' and potentiated double consciousness can be understood as 'seeing the contradictions of the system' (Gordon 2014). It is important to expose the contradictions of the mimicked gastronomic patterns of 
contemporary West Bengal by pondering on a basic question: What does our heart desire? Alexandra Jamieson, in her book Women, Food and Desire: Honor Your Cravings, Embrace Your Desire and Reclaim Your Body (2015), elaborates:

I'm a big believer that aside from providing us with the nutritional fuel we need to function at our best, food should make us happy. That's right: food should delight us, ignite us, and make us feel good. Really, really good. But, for most of us, the way we approach food does just the opposite ... It makes us feel ashamed. It makes us feel ugly and undesirable. It makes us feel wrong and unwelcome in our own bodies. And when we lose our knowledge that we have power over our relationship to it, it allows us to hide out from life (Jamieson 2015: 3 - 4).

The globalisation, commercialisation and capitalisation of European and North American food and culinary practices have manufactured a toxic and false hierarchy of 'undesirability' and 'desirability' that are based on class, caste, communal, social, cultural, geographical and economic belonging. In order to dismantle such toxic and false colonial and imperial European and North American influenced gastronomic desires and hierarchies in contemporary West Bengal the initiatives addressed below, are being taken.

\section{Khadya Mela or Food Fests}

The Bengali term Khadya Mela ${ }^{13}$ can be loosely translated into English as a food festival. In order to revive the traditional Indigenous food cultures of precolonial Bengal, the government of West Bengal, in collaboration with local municipal organisations and private sponsors organises various food festivals across all the districts of West Bengal every year. These are organised across the state broadly for two reasons - firstly, organising it across all the districts of West Bengal ensures social, cultural, geographical, communal and economic representation; and secondly, such an organisational pattern brings together the local diversities of the traditional food and culinary practices.

${ }^{13}$ Khadya means food and Mela means fests. 
Allow us here to note the food items that were prepared and sold at the food festival: 'Dum Dum Nale Jhole 2019'. The geographical place Dum Dum is located in the northern part of Kolkata and has historically been a residential area of the original residents ${ }^{14}$ of West Bengal. Therefore, the food items prepared for the festival catered to the traditional food and culinary practices of the residents there. The festival also displayed a cross-cultural and a crossnational approach by blending local Bengali ingredients with those acquired from the Europeans in the colonial and the postcolonial era. For instance, some of the local traditional dishes that were prepared were: fish and chicken kabiraji, chhanar salna, basanti polau, mutton kosha, niramish pathar mangsho, maccher dobhaaji and N.C. Das-er rosogolla.Fish and chicken kabiraji is prepared by removing the bones from the chicken and fish, mincing it and then mixing it with finely chopped onion, garlic, ginger, salt and turmeric. After mixing it thoroughly the mixture is flattened and then it is coated with biscuit powder. Thereafter, it is deep fried in mustard oil. It is then served hot as an evening snack or as a starter to meals that follow. The concept of Kabiraji was brought to the region by Muslim invaders of Bengal.

Chhanar dalna is prepared by making cheese balls that are deep fried in either mustard oil or butter. After the cheese balls have been fried, they are kept aside and a curry with ginger, garlic and onion paste is prepared. While the curry cooks, the cheese balls are soaked in it then served hot with a portion of rice. This is a common delicacy for the Bengalis, especially for vegetarians. This item is a blend of traditional Bengali and Portuguese cuisine. Basanti polau is prepared with rice, ghee, cardamom, cashew nuts, raisins and basanti colouring (a deep yellowish colour). This food item is a regular in the Bengali household, brought forth from the royal kitchen of Sova Bazar Rajbari $^{15}$.

${ }^{14}$ I have used the phrase 'original residents' in order to denote the Bengalis who have remained in West Bengal after the partition of precolonial Bengal into East Bengal (currently Bangladesh) and West Bengal in the British colonial era. During the Bangladesh Liberation War in 1971, several refugees from East Bengal arrived in West Bengal and settled widely in the southern parts of Kolkata, whereas the northern parts of Kolkata widely remained in the hands of the original residents of West Bengal.

${ }^{15}$ Sova Bazar is a historically reputed place, which is located in the northern part of Kolkata. The 'Raj Bari' or the royal palace of Sova Bazar is believed to 
Mutton kosha is another delicacy that was brought forth by the Muslim invaders and rich ingredients are used for this spicy preparation. The mutton is cooked in a pot on a low flame; ginger, garlic, onion, tomato and red chilli paste are added to the mutton. It is usually prepared in mustard oil and is served with a portion of rice, paratha, roti and luchi.

The evolution of niramish pathar manghso ${ }^{16}$ took place in the kitchen of the temple of Hindu Goddess Kali at Kalighat, Kolkata. The name of the dish in Bengali, when translated into English, is 'vegetarian mutton curry', which sounds quite peculiar. Though the term 'niramish' is translated into English as 'vegetarian', it connotes more than that. In Bengali culture, the term 'niramish' is used for dishes that are specially cooked without onion and garlic. As previously mentioned, the Bengalis believe that the use of onion and garlic were introduced into the Bengali cuisine by the Muslims, therefore they signify non-vegetarianism and anti-Hinduness; they are not the only cultural and ethnic group who adhere to this belief. With respect to this belief, still today, several Bengali households prefer to cook vegetarian dishes without onion and garlic. As such, in the temple of Hindu Goddess Kali at Kalighat, a special mutton curry without onion and garlic is prepared by the chefs at the temple's kitchen as an offering to the goddess, on a daily basis. Today, this item has become a special delicacy in many Bengali households.

Maccher dobhaaji is a traditional food item of precolonial Bengal. The Bengali word ' $m a c c h$ ' can be translated into English as 'fish' and the word 'dobhaaji' can be translated into English as 'double fried'. The dobhaaji is usually prepared with fish like Rohu, Bhetki and Pomphret. A paste of salt, turmeric, onion, garlic, ginger, hand prepared garam masala, tomato, red chilli powder, cumin powder and ginger powder is prepared, then uniformly applied on the pieces of raw fish. The battered fish is double fried in mustard oil, which means that after the fish is fried for the first time, it is taken out of the frying pan, more spices are added and then it is put back in the frying pan to be fried for the second time. Usually, it is served with a portion of rice and lentils.

N.C. Das-er rosogolla deserves special mention because historically it is believed that N.C. Das or Nobin Chandra Das discovered a white spongy

be the heart of North Kolkata because of its strong social, cultural and gastronomic impact on the habitual existence of the people there.

${ }^{16}$ In the Bengali language, 'Pathar Mangsho' means goat meat. 
sweet, which is made of cheese and sugar syrup, and he named it rosogolla ${ }^{17}$. Therefore, Nobin Chandra Das, which is also the name of a well-acclaimed sweet shop in Kolkata established by his family members, holds a significant social, cultural and historical place in the heart of the Bengalis. Some of the cross-national and cross-cultural dishes that were prepared at the food festival at Dum Dum were nolengur mousse and nolengur cupcake. Nolen gur translates to 'new jaggery' and it is extracted from date palm trees using deft skills during the winter months in West Bengal. In the festival, the local flavour of nolengur was integrated with the flavours of the European bakery items like mousses and cupcakes.

In a similar fashion, every year, several food festivals across different parts of West Bengal are organised to showcase the diverse social, cultural, communal and religious gastronomic patterns that are practised in a nonhierarchical and pluriversal manner in the contemporary era ${ }^{18}$.

\section{Aesthetical Marketing by Street Hawkers}

In order to de-racialise and decolonise the taste buds, the street food hawkers play a pivotal role through their tactics of aesthetical marketing. Aesthetical marketing is a phenomenon in which the sellers advertise their objects through their 'self-created, rhythmic and rhetorical punchlines' (Dey 2020b). On the one hand, their punchlines attract the attention of the customers and on the other it interrogates the racial prejudices that were once cultivated by the European colonisers of the traditional food of precolonial Bengal. For example, while travelling on a public bus a hawker would often sell black-coloured digestive capsules that are popularly known as hajmi golis with a Bengali punchline - Dekhte Kaalo/Khete Bhalo. The punchline can be loosely translated into English as - 'It looks black and tastes good'. These punchlines have been used several times in this sub-section because the street hawkers shout it in a rhythmic manner to gain the attention of the customers on the one side and to dismantle the racial prejudices and 'pigmentocracy' (Maart 2014:

${ }^{17}$ In Bengali language, the word 'Ros' means sugar syrup and 'Golla' means round.

${ }^{18}$ All the information that has been shared in this section is a part of the firsthand experience of Sayan Dey. He has gathered this information after attending various food festivals in the city of Kolkata. 
15) of the individuals towards the Native Bengali food dishes on the other. The second author stresses this point very directly when she asserts that the 'extent to which a hierarchy of pigmentation operates in black communities, ... where divide and conquer strategies, as a consequence of our troubled relationship to White supremacy, gave rise to narratives of light skinned/dark skinned dichotomies escalating to a point to determine logic that can only be described as perverse and traumatic' (Maart 2014: 15). Such pigmentocratic narratives of light-skinned and dark-skinned dichotomies widely influence the food of West Bengal. For instance, during my childhood I was often warned by my elders that I should avoid drinking tea and coffee because it would darken my skin. When I asked why, they would say that tea and coffee are either black or brownish in colour, therefore it has a direct impact on the colour of the human skin. So, a punchline like Kalo Chaa/Bhlao Khaa, which can be loosely translated into English as - 'Black tea tastes good', counters such illogical and colonially mimicked narratives by focusing on positive aspects.

In order to lure customers, many roadside sweet sellers will use the punchline - Kaalo Lyangcha Dekhe Mukh Bhyangchaben Na/Akbar Khaben Konodin Bhulben Na; loosely translated into English as - 'do not make a face by looking at the black colour of the lyangchas because they are so tasty that if you have one, you will crave more'. As previously mentioned, a lyangcha is a cylindrical black coloured sweet and many people continue to believe in contemporary West Bengal that black coloured sweets should not be consumed because they darken the skin.

Back in my hometown of Kolkata, there is a roadside hotel close to where I live which uses the following punchline: Jokhon Kalo-Shada Mishey Ak/Tokhon Khabarer ki Shwad Dekh.The punchline, when translated into English, reads as 'the combination of black and white enhances the taste of different foods'. In other words, in order to meet the desire of your taste buds it is important to liberate them beyond the narrow confinements of social, cultural, political, racial, communal, religious, geographical and economic binaries. This appears to be a very effective recipe for de-racialising, decolonising and de-capitalising the individual taste buds from the European and North American gastronomic influences in contemporary West Bengal.

Food blogging appears to be a very effective method of decolonising and de-racialising food and culinary practices and has become quite a phenomenon. Today, the practice of food blogging is growing at a fast rate in 
West Bengal. It is not only introducing people to the traditional dining places, snack joints and sweet shops of West Bengal, but also making an effort to remember the dismembered food and culinary practices of precolonial Bengal. As an example, let us explore the food blog titled 'Mohamushkil - a bongfoodie's quest about best foods in India', which was developed by an entrepreneur and avid food blogger named Indrajit Lahiri. Amongst several aspects of traditional Bengali cuisine, one of the most significant aspects of Bengali food culture that he elaborates upon in the blog is the culture of the 'pice hotel' in Kolkata. So, what then is a pice hotel?

According to Indrajit Lahiri, the concept of the pice hotel evolved around 1930s-40s when 'things were available in paisa and then a full meal here (the basic ones) were available at the cost of a few paisa. Hence, people used to call them paisa hotel-pais hotel-pice hotel' (2017). Food researcher Pritha Sen reflects upon this concept:

Pice hotels also known as Bhaater or Rice hotels were what were also termed Hindu hotels. They mushroomed sometime in the 1930s-40s as cheap eating houses set up to feed the hordes of daily-wage earners, students and babus who lived in the hostels and messes of Calcutta, far away from their homes in primarily East Bengal and therefore the food was primarily Bangaal, another reason why they have remained so low profile till the foodies discovered them a few years ago! The food was just like you would have at home, never knowing what your mother would put on the table, never knowing what fish your father would get back from his early morning with the accent on small fish and greens. The meals were served for $1 / 16^{\text {th }}$ of a rupee (sholoanayak taka) but everything had a price to it from the kola pata to the lebu with rice and dal being unlimited [e.i.o (cited in Indrajit Lahiri 2017)].

Thus, apart from serving homely and traditional Bengali foods, the pice hotels function as archives of social, cultural, political and culinary histories. Some of the renowned pice hotels are, among others: Swadhin Bharat Hotel, Hotel Siddheshwari Ashram, Jagannath Bhojanalayand Young Bengal Khidderpore. Swadhin Bharat Hindu Hotel was established in the year 1917 amidst various anti-colonial movements in colonial Bengal.

During the British colonial era, this hotel served as a dining space for delicious food to many freedom fighters including Chittoranjan Das, the 
founder leader of the Swaraj Party in Bengal. Apart from serving traditional delicacies like machher matha die chorchori ${ }^{19}$ and topse machh bhaja ${ }^{20}$, it functions as a repository for diverse socio-historical narratives. Hotel Siddeshwari Ashram was established in the year 1925 and it has also served as one of the most visited dining places for revolutionaries in colonial Bengal.It is highly reputed for kabirajijhol $^{21}$ and rui macher jhol ${ }^{22}$. Jagannath Bhojanalaya was established in the year 1960 and gained its reputation or its chefs from the Indian state of Orissa ${ }^{23}$. Today, it is known for serving delicious mutton curry and vetki fry ${ }^{24}$. Young Bengal Khiderpore was established in the year 1930 and it is generally reputed for its home-style Bengali foods.

Apart from pice hotels, Indrajit also talks about snack joints like Lakshmi Narayan Shaw and Sons, lassi $^{25}$ shops near the Esplanade metro station, etc. in his blog. Visiting and dining at these places is not only about satisfying one's desire for manifold food tastes, but also about revisiting one's individual as well as collective socio-cultural past. In this way, food blogs function as a powerful medium to remind one of, and allow one to recover, the traditional food and culinary practices of West Bengal.

\section{Reviving the Family-Centric Culinary Practices}

A very unique aspect of the traditional Bengali food and culinary practices is that most of the Bengali families have a rich history of preparing certain food dishes, which have originated within a respective family and is not commonly prepared by any other family and/or is not cooked in any restaurant. For instance, two dishes that have evolved from my family kitchen are doga patar

${ }^{19}$ Machher matha die chorchori refers to a dish of mixed vegetable prepared with fish head.

${ }^{20}$ Topse mach bhaja refers to a dish of deeply fried 'topse' fish.

${ }^{21}$ Kabiraji has already been described in this article. So, 'kabirajis' are made and then it is soaked in the curry. Any curry in Bengali language is referred to as 'jhol'.

${ }^{22}$ Rui machhrefers to Rohu fish and 'rui machher jhol' refers to rohu fish curry.

${ }^{23}$ It is important to note that most of the reputed male chefs in these pice hotels are believed to have come from Orissa.

${ }^{24}$ Vetki is a type of white-scaled fish.

${ }^{25}$ It is a curd-based drink and is prepared by mixing curd, water and sugar. 
jhol and notun alur chocchori. The preparation of these dishes was initiated by my great-great grandmother. Dogapata refers to the leaves of bottle gourd and pumpkin, and as mentioned earlier, jhol refers to any curry. The jhol is prepared by boiling bottle gourd and/or pumpkin leaves along with vegetables like potatoes, chicken drumsticks, papayas, pumpkins and carrots. After they are boiled, a small amount of mustard oil, or refined oil is poured into the cooking pan to mildly fry the panch phoron. After the panch phoron has been fried, the boiled vegetables are added to the cooking pan along with salt and black pepper. After all the required ingredients have been added, it is cooked for some time and then served hot, accompanied by boiled rice. Apart from being a delicacy during the humid summer season, it also functions as a homemade remedy for health problems like stomach inflammation and ulcers.

Notun alur chocchori is a vegetable dish made from onion, garlic, red chilli powder and small chunks of unpeeled potatoes. It is specifically cooked during the winter season, widely, due to two reasons: firstly, the potatoes that are used are not the usual large-sized potatoes, but the small, round ones that are cultivated exclusively during the winter season in West Bengal; secondly, this preparation is extremely hot and spicy. Therefore, it appears suitable for consumption only in cold weather conditions because its consumption during the unbearable summer heat might lead to health problems like stomach inflammation, indigestion, bloody diarrhoea, etcetera. This dish is prepared by chopping the unpeeled potatoes into small pieces. Then, along with finely chopped onions and garlic, red chilli powder, salt and turmeric powder, the potatoes are deep fried in the mustard oil. The oil that is used is measured precisely so that after the preparation of this dish is complete, the deep-fried onions, garlic and potatoes remain soaked in the fried oil. Usually, it is eaten with boiled rice as well as a serving of roti. Altogether, these initiatives are not only enabling a community to re-discover and rebuild their local and regional gastronomic traditions, but also function as an exercise to archive the past into the present and move toward a decolonial future.

\section{Not Exactly a Conclusion}

The purpose of elaborating on the traditional food and culinary practices of West Bengal and offering a critique of the European and North American imitation food patterns is not to generate narratives of gastronomic orthodoxies and chauvinisms, but rather to expose the various social, cultural, racial, 
communal, geographical, colonial and political factors that motivated people to disown their traditional consumption patterns and impersonate the European colonisers and the North American imperialists. It is important to illustrate how the social, cultural, historical and sensual desire of taste buds have been captivated, colonised and enslaved by the toxic seductions of colonialism and capitalism.

The purpose here is not to conclude this article with a definite set of solutions but to develop a depolarised, pluriversal platform for dialogues, polylogues, agreements and disagreements, which will enable us to holistically involve ourselves in the exercise of mothofatso or a continuous rehumanisation of the social, cultural, historical, communal and geographical traditions of Indigenous food of West Bengal. The continual rehumanisation will also motivate us to de-hierarchise, de-capitalise and embrace different food from different parts of the world and successfully move from 'elimination to connections' (Gordon 2020).

\section{Acknowledgements:}

We are extremely grateful to Professor Lewis Gordon from the University of Connecticut and Professor Puleng Segalo from the University of South Africa for their rich feedback and suggestions during the UNISA Summer School of 2020 where Sayan Dey presented a segment of this article.

Rozena Maart wishes to acknowledge the National Institute for the Humanities and Social Sciences [NIHSS] for the grant that facilitated some of this research under, the 'Race, Space and the City' project. It was during the research on the colonisation of the Cape and understanding the history of the food that was brought into the Cape through enslavement, that previous held communal beliefs about food and colonisation sought greater relevance in some of my work, thus fostering greater understanding of the relationship between the establishment of the city, and the colonisation of the food that fed the usurpers and colonisers of the $17^{\text {th }}$ century.

\section{References}

Achaya, K.T. 1991. The Food Industries of British India. New Delhi: Oxford University Press. 
Agarwal, P. 2016. Caste on Your Plate: A Tale of Food Snobbery in India. The

Quint. https://www.thequint.com/news/india/caste-onyour-plate-a-taleof-food-snobbery-in-india (Accessed on 2 August 2020.)

Arendt, E.K. \& E. Zannini 2013. 'Rice': Cereal Grains for the Food and Beverage Industries. Cambridge: Woodhead Publishing.

https://doi.org/10.1533/9780857098924.114

Arpita 2020. 'Panch Phoron: Indian Five-Spice'. Gastronomic Bong.

https://thegastronomicbong.com/panch-phoron-indian-five-spice/

(Accessed on 5 August 2020.)

Banerji, C. 2005. Life and Food in Bengal. New Delhi: Penguin Books.

Basu, B. 2004. Bhojan Shilpi Bangali. Kolkata: BikalpaPrakashani.

Beams, J. 1961. Memoirs of a Bengal Civilian. London: Chatto and Windus.

Bhabha, H. 1990. The Location of Culture. London and New York: Routledge. Cabral, A. [1970] 2009. National Liberation and Culture. BLACKPAST. https://www.blackpast.org/global-african-history/1970-amilcar-cabralnational-liberation-and-culture/

(Accessed on 29 July 2020.)

Biko, S. 1978. I Write What I Like. New York: Heinemann.

Bose, K. (ed.). 2004. Ramprasad Bharatchandra Rachanasamagra. Kolkata: Reflect Publications.

Burton, D. 1993. The Raj at the Table: A Culinary History of the British in India. London and Boston: Faber.

Cesaire, A. 2001. Discourse on Colonialism. Pinkham, J. (trans.). New York: Monthly Review Press.

Chakrabarty, D. 1989. Rethinking Working-class History: Bengal 1890 - 1940. Delhi: Oxford University Press.

https://doi.org/10.1515/9780691188218

Chakravarti, M. 2011. Kabikankan - Chandi (Chandimangal). Bandhopadhyay, S. \& V. Chowdhury (eds.). Kolkata: University of Calcutta Press.

Chaudhury, A. 2020. Colonial and Ethnic Tensions in the Politics of 'Authenticity' and Street Food Production and Consumption in Late Colonial and Contemporary West Bengal, India. Academia.edu. https://www.academia.edu/12342221/Colonial and Ethnic Tensions in the_Politics_of_Authenticity_and_Street_Food_Production_and_Consu mption in Late Colonial and Contemporary West Bengal India (Accessed on 23 July 2020.) 
Collingham, E.M. 2001. Imperial Bodies: The Physical Experience of the Raj, c. 1800 - 1947. Cambridge: Polity Press.

Curtis, C. 1807. An Account of the Diseases in India, as they Appeared in the English Fleet, and in the Naval Hospital at Madras, in 1782 and 1783; with Observations on Ulcers, and the Hospital Sores of that Country, etc., etc. Edinburgh: W. Laing, Longman and J. Murray.

Dey, S. 2020a. The Burden of European Colonial Gastronomy in Contemporary West Bengal. The Indian Hour.

https://www.theindianhour.com/post/the-burden-of-european-colonialgastronomy-in-contemporary-west-bengal

(Accessed on 20 January 2020.)

Dey, S. 2020b. De-racializing Taste Buds through Aesthetical Marketing: Food Hawkers of Kolkata. The Indian Hour. https://www.theindianhour.com/post/de-racializing-taste-buds-throughaesthetical-marketing-food-hawkers-of-kolkata (Accessed on 31 March 2020.)

Dhillion, A. 2014. In India, Caste System Ensures you are What you Eat. Post Magazine.

https://www.scmp.com/magazines/post-magazine/article/1558061/youare-what-you-eat (Accessed on 2 August 2020.)

Doctor, V. 2008. Dalit Food: How it Became a Means of Oppression. The Economic Times. https://economictimes.indiatimes.com/the-leisurelounge/dalit-food-how-it-became-a-means-of-

oppression/articleshow/2945790.cms

(Accessed on 2 August 2020.)

Fanon, F. 1963. The Wretched of the Earth. Farrington, C. (trans.). New York: Grove Press.

Fanon, F. 1967. Black Skin, White Masks. Markmann, C.L. (trans.). New York: Grove Press.

Gordon, L.R. 2020. Freedom, Justice, and Decolonization. New York: Routledge.

https://doi.org/10.4324/9781003112594

Gordon, L.R. 2014. Living Thought, Living Freedom: A Lecture in Black Existential Philosophy. SIUE Lovejoy Library. YouTube. https://www.youtube.com/watch?v=qDpepZOeAqg\&t=279s

(Accessed on 31 December 2019.) 
Gordon, L.R. 2020. Some Thoughts on Decolonization, Decoloniality, Racism, and Challenges of Citizenship in Communities of Learning. Alternation Special Edition 33.

https://doi.org/10.29086/2519-5476/2020/sp33a3

Habib, I. 2014. The Agrarian System of Mughal India 1556 - 1707. New Delhi: Oxford University Press.

Halder, S. 2016. Our Food, Their Food: A Historical Overview of the Bengali Platter. Sahapedia.org. https://www.sahapedia.org/our-food-their-foodhistorical-overview-of-the-bengali-platter

(Accessed on 31 October 2019.)

Hunt, S. \& C. Holmes 2015. Everyday Decolonization: Living a Decolonizing Queer Politics. Journal of Lesbian Studies 19,2: 154 - 172.

https://doi.org/10.1080/10894160.2015.970975

PMid:25760993

Jamieson, A. 2015. Women, Food, and Desire: Honor Your Cravings, Embrace Your Desires, Reclaim Your Body. New York: Simon and Schuster.

Lahiri, I. 2017. Pice Hotels to Try Before You Die in Kolkata - Part I. Food Blog Mohamushkil - a bong foodie's quest about best foods in India. https://moha-mushkil.com/pice-hotel-kolkata-part-1/

(Accessed on 5 January 2020.)

Lefebvre, H. 1991. Critique of Everyday Life - Volume 1. Moore, J. (trans.). London and New York: Verso Books.

Maart, R. 2004. When Black Consciousness Meets White Consciousness in Feminist Organizations. Cahiers Charles 5,40: 71 - 93.

https://doi.org/10.3406/cchav.2006.1460

Maart, R. 2014. 'Race'. In Ferrante, J., M. Seedat-Khan, Z. Jansen \& R. Smith (eds.): Sociology: A South African Perspective. Cape Town: Cengage Publishers.

Maart, R. 2016. Rosa's District Six. Toronto: Tsar Publications.

Maart, R. \& S. Dey [2021.] Palates of Pleasure. (Forthcoming.)

Martin, J.R. 1837. Notes on the Medical Topography of Calcutta. Calcutta: Bengal Military Orphan Press.

Metcalf, T.R. 1994. Ideologies of the Raj. Cambridge: Cambridge University Press.

Mudimbe, V-Y. 2013. On African Fault Lines: Meditations on Alterity Polittics. (Thinking Africa.) Pietermaritzburg: UKZN Press. 
Mukhopadhyay, B. 2007. Pak Pranali. Kolkata: Ananda Publishers.

Murshid, G. 2008. Hajar Bacharer Bangali Sanskriti. Dhaka: Abosar Publications.

N.a. Food Festival: Dum Dum Nale Jhole 2019. Dumdum cultures.in.

http://www.dumdumcultures.in/food-festival-dum-dum-nale-jhole-2019/ (Accessed on 18 March 2020.)

N.a. 1915. Brihad-dharma Purana. Banerji, S.C. (trans.). Lucknow: Indian Commercial Press.

N.a. 2015. Weight Loss Secrets: 5 Things You Should Never Eat at Night. Ndtv.com.

https://www.ndtv.com/sites/fitnesschallenge/detailsblog/weightlosssecret s5thingsyoushouldnevereatatnight-

770724\#: :text=White\%20rice\%20is\%20just\%20as,of\%20fiber\%2C\%2 0vitamins\%20and\%20nutrients

(Accessed on 20 July 2020.)

N.a. 2020. Panch Phoran: Indian Five Spice. SPICEography.

https://www.spiceography.com/panch-

phoran/\#: : text=While\%20the\%20true\%20history\%20of,is\%20the\%20b asis\%20of\%20creation (Accessed on 30 June 2020.)

N.a. Indian Outfits and Establishments: Practical Guide for Persons to Reside in India. London: Upcott Gill.

Orme, R. 1971. Of the Government and People of Indostan. Lucknow: Pustak Kendra.

Parashara, R.M. 2015. The Vishnu Purana. Wilson, H.H. (trans.). New York: CreateSpace Independent Publishing Platform.

Ramose, M.B. 1999. African Philosophy through Ubuntu. Harare: Mond Books.

Ray, P. 1987. Banglar Khabar. Kolkata: Sahityaloke.

Ray, U. 2012. Eating 'Modernity': Changing Dietary Practices in Colonial Bengal. Modern Asian Studies 46,3: 703 - 729.

https://doi.org/10.1017/S0026749X11000515

Risley, H. 1908. The People of India. Calcutta: Thacker, Spink and Co.

Samal, A.K. 2017. Dalit Homes Burn While 'Upper' Cast Arsonists Roam Scot Free. Video Volunteers. https://www.videovolunteers.org/dalit-homeburned-in-odisha/?gclid=EAIaIQobChMIpqn229776gIVjw4rCh3Y-

w7uEAAYASAAEgLU4vD BwE

(Accessed on 2 August 2020.) 
Sen, C.T. 1997. The Portuguese Influence in Bengali Cuisine. In Walker, H. (ed.): Food on the Move: Proceedings of the Oxford Symposium on Food and Cookery 1996. Devon: Prospect Books.

Sengupta, J. 2010. Nation on a Platter: The Culture and Politics of Food and Cuisine in Colonial Bengal. Modern Asian Studies 44,1: 81 - 98. https://doi.org/10.1017/S0026749X09990072

Sriharsa 1836. The Naishada-Charita, or the Adventures of Nala Raja of Naishada. Calcutta: Baptist Mission Press.

Waghmore, S. 2017. In Charts: Vegetarianism in India has More to Do with Caste Hierarchy than Love for Animals. Scroll.

https://scroll.in/article/833178/vegetarianism-in-india-has-more-to-dowith-caste-hierarchy-than-love-for-animals

(Accessed on 2 August 2020.)

wa Thiong'o, N. 1986. Decolonising the Mind: The Politics of Language in African Literature. New York: Heinemann.

Wyvern, A.K-H. 1885. Culinary Jottings: A Treatise in Thirty Chapters on Reformed Cookery for Anglo-Indian Exiles. Madras: Higginbotham and Co.

Sayan Dey

Postdoctoral Fellow University of the Witwatersrand Johannesburg, South Africa sayandey417@gmail.com

Rozena Maart Associate Professor Gender Studies, Social Sciences University of KwaZulu-Natal Durban South Africa

International Research Ambassador University of Bremen Germany rozmaart@gmail.com 